\title{
Human Mast Cells Stimulate Vascular Tube Formation Tryptase Is A Novel, Potent Angiogenic Factor
}

\author{
Robyn J. Blair, ${ }^{\star}$ Hong Meng, ${ }^{*}$ Mary J. Marchese, ${ }^{\star}$ Shunlin Ren,, Lawrence B. Schwartz, ${ }^{\ddagger}$ Marcia G. Tonnesen, ${ }^{\star}$ \\ and Barry L. Gruber* \\ *Departments of Medicine and Dermatology, SUNY at Stony Brook and Department of Veterans Affairs Medical Center, Northport, \\ New York 11768; and the ${ }^{\ddagger}$ Department of Internal Medicine, Virginia Commonwealth University, Richmond, Virginia $23298-0263$
}

\begin{abstract}
The presence of mast cells near capillary sprouting sites suggests an association between mast cells and angiogenesis. However, the role of mast cells in blood vessel development remains to be defined. In an attempt to elucidate this relationship, we investigated the effect of human mast cells (HMC-1) and their products on human dermal microvascular endothelial cell (HDMEC) tube formation. Coculture of HMC-1 with HDMEC led to a dose-response increase in the network area of vascular tube growth. Moreover, the extent of neovascularization was enhanced greatly when HMC-1 were degranulated in the presence of HDMEC. Further examination using antagonists to various mast cell products revealed a blunted response (73-88\% decrease) in the area of vascular tube formation if specific inhibitors of tryptase were present. Tryptase $(3 \mu \mathrm{g} / \mathrm{ml})$ directly added to HDMEC caused a significant augmentation of capillary growth, which was suppressed by specific tryptase inhibitors. Tryptase also directly induced cell proliferation of HDMEC in a dosedependent fashion ( $2 \mathrm{pM}-2 \mathrm{nM})$. Our results suggest that mast cells act at sites of new vessel formation by secreting tryptase, which then functions as a potent and previously unrecognized angiogenic factor. (J. Clin. Invest. 1997. 99: 2691-2700.) Key words: mast cells • angiogenesis $\bullet$ neovascularization $\cdot$ tryptase $\cdot$ endothelial cells
\end{abstract}

\section{Introduction}

The formation of new blood vessels is critical, not only for a variety of normal physiological processes, such as wound healing and placental development $(1,2)$, but also in many pathological conditions, including solid tumor growth and diabetic retinopathy $(3,4)$. As exemplified in rheumatoid arthritis and other chronic inflammatory joint diseases, increased vascular proliferation can facilitate joint cartilage destruction (5). Recent studies have explored the effect of specific growth factors on angiogenesis, but limited knowledge exists regarding the regulation of angiogenesis by host cells in vivo. Mast cells, which have been shown to accumulate near sites of new capillary sprouting, have long been implicated in angiogenesis, but relatively little experimental data has accumulated $(6,7)$. We postulated that mast cells are recruited to sites of neovascular-

Address correspondence to Barry L. Gruber, M.D., Associate Professor of Medicine and Dermatology, HSC 16-040, SUNY at Stony Brook, Stony Brook, NY 11794-8161. Phone: 516-444-2349; FAX: 516-444-3475; E-mail: BGruber@epo.som.sunysb.edu

Received for publication 9 December 1996 and accepted in revised form 14 March 1997.

The Journal of Clinical Investigation

Volume 99, Number 11, June 1997, 2691-2700 ization and then release products that stimulate vascular tube formation. The recruitment of mast cells to these sites may be governed by angiogenic factors, as we have reported previously (8).

The complex phenomenon of angiogenesis begins with degradation of the basement membrane by cellular proteases. This allows endothelial cells to penetrate and migrate into the extracellular matrix and then proliferate. In the final stages of this process, the endothelial cells align themselves to form capillary or tubelike structures. These new structures then form an anastomosing network that undergoes significant remodeling and rearrangement before fully functioning capillaries exist $(6,9)$. The process of angiogenesis is regulated by numerous factors, including growth factors, integrins, and components of the basement membrane.

A widely used in vitro model for studying angiogenesis involves culturing endothelial cells on extracted basement membrane matrix, whereupon tube formation can be monitored. We examined the influence of a widely used human mast cell line (HMC-1 $)^{1}$ using this basic cell culture model. It was observed that secreted products from these mast cells stimulated microvascular endothelial cells to rapidly differentiate and mature into vascular tubes in vitro. Additional studies, intended to delineate the responsible mast cell mediator, disclosed that the serine endopeptidase tryptase (10) was largely responsible for the angiogenic effect. This tetrameric enzyme is released in abundant quantity from mast cells that are ionically bound to heparin proteoglycan, which stabilizes tryptase in its enzymatically active form (11). Although two genes for human tryptase have been identified, $\beta$-tryptase appears to account for the enzymatically active enyme found in human lung mast cells and the mast cell leukemia cell line HMC-1 $(12,13)$. Our results confirm that mast cells markedly enhance overall capillary growth and, specifically, identify tryptase as a previously unrecognized but critical factor in regulating angiogenesis.

\section{Methods}

Materials. Endothelial basal medium MCDB 131 and bovine brain extract were purchased from Clonetics (San Diego, CA); EGF, Matrigel Basement Membrane Matrix, and Growth Factor Reduced Matrigel Matrix were obtained from Collaborative Biomedical Products (Bedford, MA). Human serum was obtained from BioWhittaker, Inc. (Walkersville, MD). MEM, gentamicin, and low molecular weight heparin (high purity) were from GIBCO BRL (Gaithersburg, MD). Diff Quik was purchased from Baxter Healthcare Corp. (McGaw Park, IL). Hydrocortisone, dibutyryl cAMP, calcium ionophore

1. Abbreviations used in this paper: BABIM, bis(5-amidino-2-benzimidazo-lyl)methane; bFGF, basic fibroblast growth factor; GFR-Matrigel, growth factor-reduced Matrigel; HDMEC, human dermal microvascular endothelial cells; HMC-1, human mast cell; rLDTI, recombinant leech-derived tryptase inhibitor. 
A23187, PMA, and dextran sulphate $\left(M_{\mathrm{r}} 500,000\right)$ were obtained from Sigma Immunochemicals (St. Louis, MO). Vitrogen 100 Type I collagen was obtained from Collagen Biomedical (Palo Alto, CA). Recombinant basic fibroblast growth factor (bFGF) was purchased from R \& D Systems, Inc. (Minneapolis, MN). Bis(5-amidino-2-benzimidazo-lyl)methane (BABIM), a nontoxic potent tryptase inhibitor (14), was kindly provided by Dr. R. Tidwell (University of North Carolina, Chapel Hill, NC). Recombinant leech-derived tryptase inhibitor (rLDTI), also a nontoxic inhibitor (15), was a generous gift from Dr. Christian P. Sommerhoff (Abteilung für Klinische Chemie und Klinische Biochemie in der Chirurgischen Klinik und Poliklinik, Munich, Germany).

Tryptase was purified to homogeneity from the human lung by high salt extraction, immunoaffinity chromatography, and heparinagarose chromatography, as described previously (11). Tryptase activity was quantitated by monitoring hydrolysis of tosyl-L-Gly-ProLys- $p$-nitroanilide using a standard spectrophotometric assay at $405-\mathrm{nm}$ wavelength (11). Tryptase preparations used in these experiments had specific activities between 80 and $100 \mathrm{U} / \mathrm{mg}$. $1 \mathrm{U}$ equals $1 \mu \mathrm{mol}$ of substrate cleaved per minute at room temperature. Molar concentrations of tryptase were determined using the molecular weight of the tetramer $(134 \mathrm{kD})$. The tryptase inhibitors BABIM and rLTDI were capable of reducing hydrolytic activity by $\sim 90 \%$ in the standard assay.

Cell culture. Human dermal microvascular endothelial cells (HDMEC) were isolated from human foreskins by modifications of previously published methods $(16,17)$. Briefly, HDMEC were released from foreskins by trypsinization and were purified by gradient centrifugation. Cells were initially cultured in $1 \%$ gelatin-coated tissue culture Petri dishes (35-mm; Falcon Plastics, Cockeysville, MD), and the subcultured cells were then grown to confluence in Falcon T-75 flasks before harvesting for use in experiments. HDMEC were cultured in endothelial basal media MCDB 131 with $20 \%$ heat-inactivated human serum, $100 \mu \mathrm{l} / \mathrm{ml}$ gentamicin, $1 \mu \mathrm{g} / \mathrm{ml}$ hydrocortisone, $17.5 \mu \mathrm{g} / \mathrm{ml}$ dibutyryl cAMP, $10 \mathrm{ng} / \mathrm{ml} \mathrm{EGF}$, and $0.4 \% \mathrm{vol} / \mathrm{vol}$ bovine brain extract. HDMEC were free of contaminating fibroblasts, as assessed by von Willebrand factor staining, uptake of acetylated low density lipoprotein (Dil-Ac-LDL), and a typical cobblestone morphology of confluent monolayers. HDMEC were used for experiments between the 6th and 10th passages.

Preparation of mast cell-conditioned media. The human mast cell line HMC-1, kindly provided by Dr. J. Butterfield (Mayo Clinic, Rochester, MN), was maintained in fresh culture medium as described originally (18). These cells displayed granular pale metachromasia upon acidic toluidine blue staining and reacted by immunohistochemistry with G-3 mAb specific for tryptase $(19,20)$. Secreted products from these cells (henceforth referred to as releasates) were generated after degranulation by exposure of HMC-1 to calcium ionophore A23187. Optimal stimulation and release were achieved by incubating HMC- 1 cells $\left(3 \times 10^{6} / \mathrm{ml}\right)$ for $8 \mathrm{~h}$ with $500 \mathrm{ng} / \mathrm{ml} \mathrm{A23187}$ at $37^{\circ} \mathrm{C}$. The tryptase content of these releasates ranged from 1 to 3 $\mathrm{nM}$. At least three different preparations of HMC-1 releasates were used for the studies described below. All experiments were performed using A23187 (500 ng/ml) in culture media as a negative control, in the absence of mast cells, for comparative purposes.

Collagen gel preparation. $7 \mathrm{vol}$ of Vitrogen 100 type I collagen $(3.1 \mathrm{mg} / \mathrm{ml})$ was mixed with $1 \mathrm{vol}$ of $10 \times \mathrm{MEM}, 1$ vol of sodium bicarbonate $(23.5 \mathrm{mg} / \mathrm{ml})$, and $4.2 \mu \mathrm{l} / \mathrm{ml}$ of gentamicin in a sterile $15-\mathrm{ml}$ tube on ice (21). After the $\mathrm{pH}$ was adjusted to neutral, 1 vol of distilled water was added. The mixture was quickly added to a 24-well plate $(300 \mu \mathrm{l} / \mathrm{well})$ and allowed to gel for $30 \mathrm{~min}$ at $37^{\circ} \mathrm{C}$. Once gelled, the wells were washed twice with endothelial cell basal medium and then incubated for $2 \mathrm{~h}$ with HDMEC culture medium.

Matrigel endothelial cell tube formation assays. HDMEC plated on Matrigel-coated wells rapidly form a dense capillary network. Growth factor-reduced Matrigel (GFR-Matrigel), prepared from the Engelbreth-Holm-Swarm tumor and treated to deplete endogenous growth factors (Collaborative Biomedical, Bedford, MA), was al- lowed to gel for $30 \mathrm{~min}$ at $37^{\circ} \mathrm{C}$ after coating 24-well plates $(250 \mu \mathrm{l} /$ well) (22). The advantage of using GFR-Matrigel over standard Matrigel is that differences in tube density in the presence of exogenous stimulants are more readily appreciated. In our experience, HDMEC tube formation was significantly slower under naive conditions in GFR-Matrigel compared to standard Matrigel. HDMEC were seeded at a density of $4-5 \times 10^{4}$ cells/well in $1 \mathrm{ml}$ of complete medium, and the effect of cell products was monitored after the addition of either HMC-1 releasate or cocultured HMC-1 cells. For certain experiments, cycloheximide $(\sim 25 \mu \mathrm{g} / \mathrm{ml}$; Sigma Immunochemicals) or actinomycin D ( $\sim 6 \mu \mathrm{g} / \mathrm{ml}$; Sigma Immunochemicals $)$ were added to the cells to determine the dependency of tube formation on translation or transcription, respectively (23).

Plates were incubated at $37^{\circ} \mathrm{C}$ for $16 \mathrm{~h}$. The medium was aspirated, and the cells were fixed and stained with Diff Quik. The area of the tube growth was visualized with a Diaphot microscope (internal magnification of $2.5 \times$; Nikon Inc., Melville, NY) at a magnification of $10 \times$. Initially, photographs of three to four random optical fields were taken with a Nikon N2000 camera on a phase microscope at magnifications of both $4 \times$ and $10 \times$. Experiments to be quantitated were examined with a Nikon Diaphot microscope, as described above, which was directly interfaced to a video monitor linked to a Macintosh Quadra 800 computer. Several random images per well were obtained with Adobe Photoshop, and final quantitation was done by MetaMorph Imaging System, an image analysis program.

Tube inhibition assay. To identify the responsible mast cellderived mediator that regulates angiogenesis, antagonists or inhibitors of specific mast cell products were analyzed for their effect on the tube formation assay. The tryptase inhibitor BABIM at 50nM was incubated with HMC-1 releasate for $30 \mathrm{~min}$ in 5-ml round-bottom tubes. In separate experiments, tryptase was incubated with rLDTI $(25 \mu \mathrm{M})$ for $30 \mathrm{~min}$ in $5-\mathrm{ml}$ round-bottom tubes. The pretreated releasates were then added to wells coated with Matrigel. HDMEC $\left(4-5 \times 10^{4}\right)$ were immediately seeded on the wells. Plates were incubated at $37^{\circ} \mathrm{C}$ for $16 \mathrm{~h}$ and then fixed and stained with Diff Quik. Images of the wells were obtained, and the percent inhibition, compared to HMC-1 releasates, was analyzed as described above.

In separate experiments, tryptase $(3 \mu \mathrm{g} / \mathrm{ml})$ stabilized by heparin glycosaminoglycan at $\sim 1.2$ molar ratio (11), was added to assess its angiogenic potential. Heparin stabilizes tryptase in its physiologically active tetrameric conformation (11). Identical concentrations of heparin were added to cells as a control. For certain experiments, dextran sulphate, in concentrations to achieve $\sim 1.2$ molar ratio in PBS and $0.1 \%$ BSA, was used as an alternative tryptase stabilizer (24). The dependency on a proteolytically active tetrameric enzyme conformation (20) was also tested by allowing tryptase to incubate in physiologic buffer for several hours in the absence of any glycosaminoglycan before assessing its angiogenic potential.

Collagen endothelial cell tube formation assays. Separate experiments were performed using purifed collagen as a substratum for HDMEC tube formation. These experimental conditions are less permissive for spontaneous tube formation, as compared to Matrigel preparations. In these studies, HDMEC $\left(10^{5}\right)$ were added to each collagen-prepared well (essentially as described above) in cell culture medium in the presence or absence of a stimulant. Wells were incubated with PMA at 6,30 , and $60 \mathrm{ng} / \mathrm{ml}$, or with bFGF at 3, 30, and $60 \mathrm{ng} /$ $\mathrm{ml}$. These growth factors were compared to HMC-1 releasate diluted 1:10 with cell culture medium. The tubes were analyzed at day 10 , and the area of vascular tube formation was determined. Replicate wells were analyzed in each experiment, and each experiment was repeated at least three times.

Confocal microscopy and scanning electron microscopy. HDMEC $\left(4-5 \times 10^{4}\right)$ on $500 \mu l$ GFR-Matrigel were treated with either tryptase or HMC-1 releasate (1:10 dilution) and incubated for $16 \mathrm{~h}$. Samples were fixed in either $2 \%$ paraformaldehyde for confocal microscopy or $2.5 \%$ glutaraldehyde and $2 \%$ paraformaldehyde, and were washed in $2 \times$ PBS for scanning microscopy. The samples for scanning microscopy underwent a final fixation in osmium tetroxide, followed by al- 
cohol dehydration, critical point drying with $\mathrm{CO}_{2}$, and sputter coating with gold. The capillary tube formation was examined using either a confocal microscope (Odyssey; Noran Instruments Inc., Middleton, WI) in reflective mode or a scanning electron microscope (JSM; J.E.O.L. USA, Inc., Peabody, MA) at the Microscopy Imaging Center, SUNY at Stony Brook. The images of the tube-like structures were sequentially obtained $(0.25-\mu \mathrm{m}$ serial sections) using reflective confocal microscopy, and were then subsequently analyzed by a computer-assisted software program (Voxelview; Vital Images) and reconstructed in an effort to provide a series of cross-sectional views for analysis (with the kind assistance of David Colfesh, Microscopy Imaging Center, SUNY at Stony Brook).

Endothelial cell proliferation assay. $100 \mu \mathrm{l}$ of HDMEC cells per well $\left(5 \times 10^{4}\right.$ cells $\left./ \mathrm{ml}\right)$ were plated in EBM with $2 \%$ serum in 96 -well tissue culture plates, and were incubated at $37^{\circ} \mathrm{C}$ for $4-6 \mathrm{~h}$ to allow the cells to adhere. Test substances and controls were added in triplicate, and the plate was incubated at $37^{\circ} \mathrm{C}$ in $5 \% \mathrm{CO}_{2}$ for $72 \mathrm{~h}$. HDMEC mitogenesis was determined using a nonradioactive cell proliferation assay system consisting of tetrazolium and phenazine methosulfate (Promega). Results were read using an ELISA reader at $490 \mathrm{~nm}$.

Statistical analysis. Data were analyzed with the unpaired Student's $t$ test and the Mann-Whitney test.

\section{Results}

Effect of HMC-1 releasate and cocultured HMC-1/HDMEC on vascular tube formation. Incubation of HDMEC on GFR-
Matrigel without exogenous stimulation revealed that HDMEC rearranged or aligned themselves in an organized manner within 1 or $2 \mathrm{~h}$ of plating. By 16-18 $\mathrm{h}$ after plating, the tubeforming process reached a maximum. In the absence of stimulation, HDMEC formed only a small number of short, incomplete tubes. The majority of the tubes were not linked to one another, but remained close to the cell body from which it was derived. After $18 \mathrm{~h}$, the tubes began to disintegrate, and their networks became less defined. In the presence of either cycloheximide or actinomycin D, tube formation was completely inhibited (data not shown).

The effect of HMC-1 releasates on HDMEC was noted by $6 \mathrm{~h}$ after plating on Matrigel. Visual differences were obvious as compared to untreated control cells (Fig. 1, $a$ and $b$ ). The untreated HDMEC formed significantly less tubes in comparison to the stimulated cells. A majority of the control cells formed the characteristic monolayer observed when HDMECs are plated on plastic rather than organized into tubes. After a 12-h incubation, the cells treated with HMC-1 releasate further differentiated into an expansive tube network and became progressively denser (Fig. $1 d$ ), whereas most of the control cells remained as individual clusters or ovoid colonies (Fig. $1 \mathrm{c}$ ). By $16 \mathrm{~h}$, the boundaries of the stimulated tubes were sharply defined, elongated, and extended more from the cell body. Furthermore, a majority of the endothelial cells formed
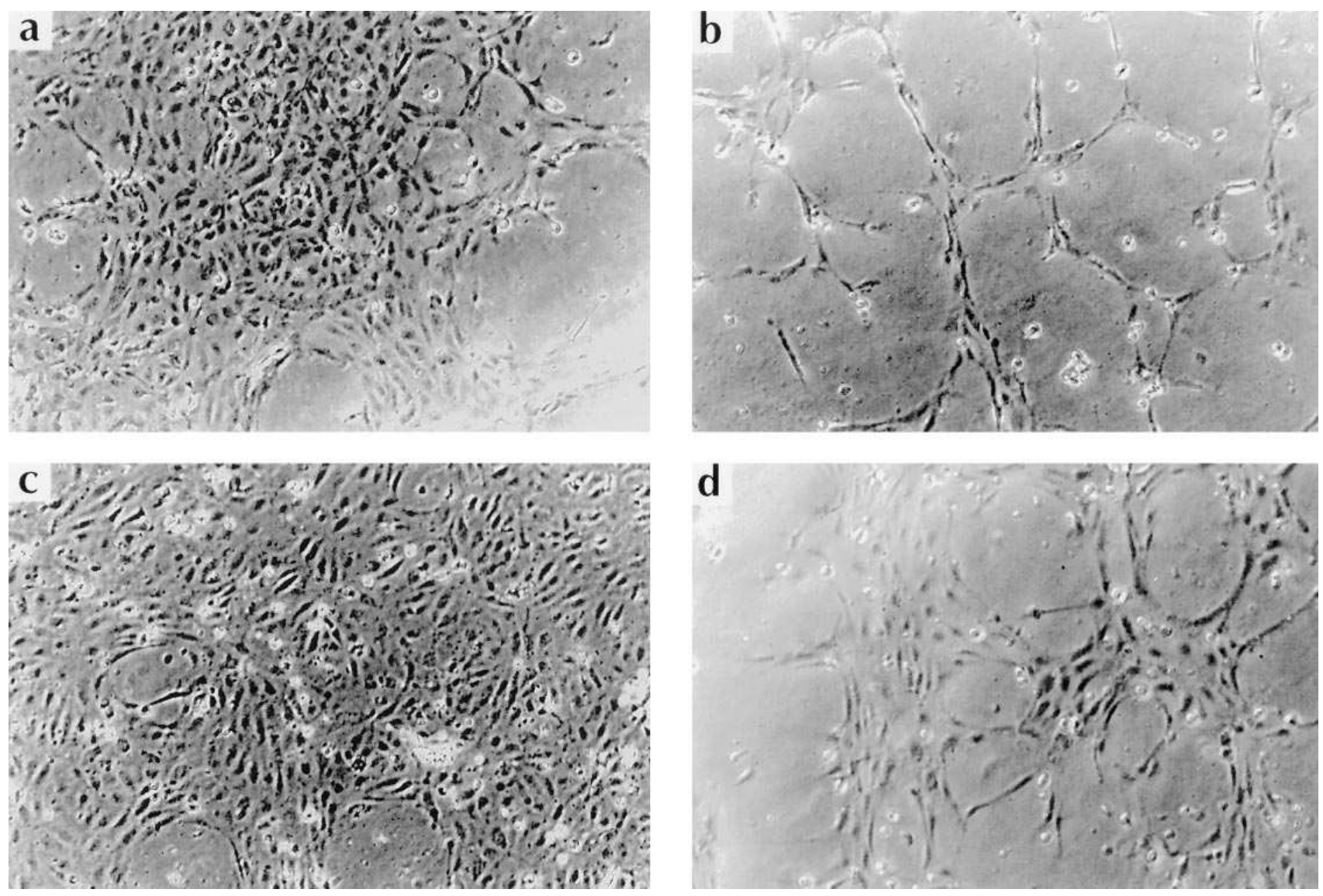

Figure 1. Effect of HMC-1 releasate on in vitro angiogenesis. HDMEC were seeded on GFR-Matrigel in 24 -well plates at $4-5 \times 10^{4}$ cells per well in the presence or absence of specific stimulants. The cells were fixed and stained with Diff Quik and photographed at various time points with a Nikon N2000 camera on a phase microscope at $4 \times$ magnification, as described in Methods. (a) Control at $6 \mathrm{~h}$ showing HDMEC without additional stimuli. (b) HMC releasate (1:10 dilution) added to HDMEC, showing vascular tubes at $6 \mathrm{~h}$. (c) Control at $12 \mathrm{~h}$ showing HDMEC without additional stimuli. (d) HMC releasate (1:10 dilution) added to HDMEC, showing vascular tubes at $12 \mathrm{~h}$. 


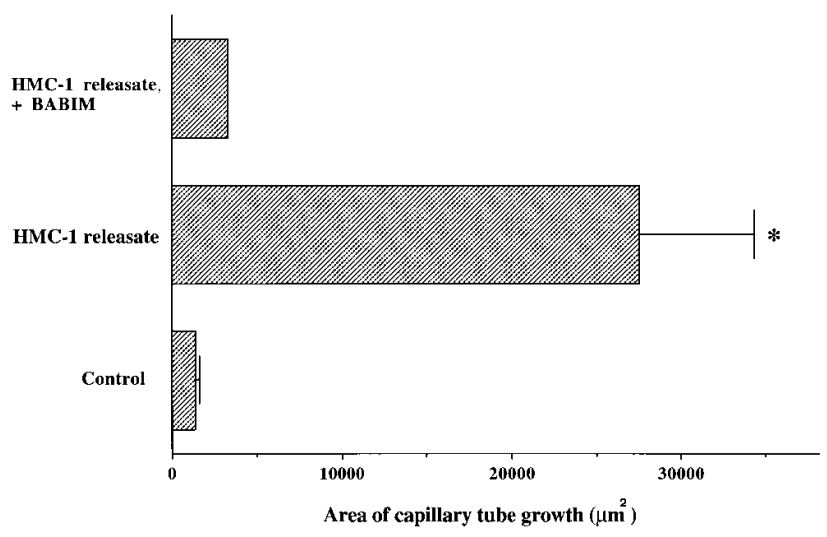

Figure 2. Effect of HMC-1 releasate on HDMEC seeded on GFRMatrigel. HDMEC $\left(4-5 \times 10^{4}\right)$ were incubated on GFR-Matrigel in 24-well plates. HMC-1 releasate (1:10 dilution) was added to wells in the presence or absence of BABIM $(50 \mathrm{nM})$. Plates were incubated for $16 \mathrm{~h}$ and then fixed and stained. The area of capillary growth was quantitated with MetaMorph Imaging System, an image analysis program. Data are expressed as the mean $\pm \mathrm{SD}(n=4)$ from images of random fields at $10 \times$ magnification. The asterisk indicates that the value is significantly greater than corresponding control value $(P<0.001)$.

tubes. Overall, cells treated with HMC-1 releasate resulted in a more extensive network of interconnecting tubes compared to untreated HDMEC. By quantitating the surface area occupied by tubes (see Methods), we observed that incubation of HDMEC with HMC-1 releasate greatly increased both the area of the capillary network and the average length of tubes. The calculated total area of tube growth in HMC-1 releasatetreated cells increased more than 20 -fold over the controls (Fig. 2).

To determine if HMC-1 directly cocultured with HDMEC stimulates tube growth, HMC-1 were seeded at varying ratios with HDMEC. The addition of resting HMC-1 mast cells without a secretagogue caused an increase in tube growth (data not shown). Furthermore, when HMC-1 were degranulated with calcium ionophore A23187 in coculture, there was an even greater increase in tube formation. A clear-cut dose response was observed at HMC-1/HDMEC ratios of 1:1, 1:10, and 1:100 (Fig. 3). The ionophore alone had no detectable effect on the endothelial cell tube formation directly.

Since tryptase is a major secretory product of human mast cells, purified tryptase was added directly to HDMEC. Tryptase (stabilized with either heparin or dextran sulphate) induced a 10-fold increase in capillary tube formation compared to the controls (Fig. 4 top). The heparin and dextran sulphate controls produced minimal tube growth that was not significantly different from endothelial cell control values. The vascular tubes resulting from tryptase treatment were clearly defined with extensive networks, as compared to untreated cells. A typical dose response was observed when increasing amounts of typtase/heparin was added to endothelial cells (Fig. 4 bottom). The graph indicates that heparin alone contributes $\sim 25 \%$ to total capillary tube growth, while tryptase (stabilized with heparin) is responsible for the majority of this enhancement.

To determine if tryptase mediated tube formation by af-

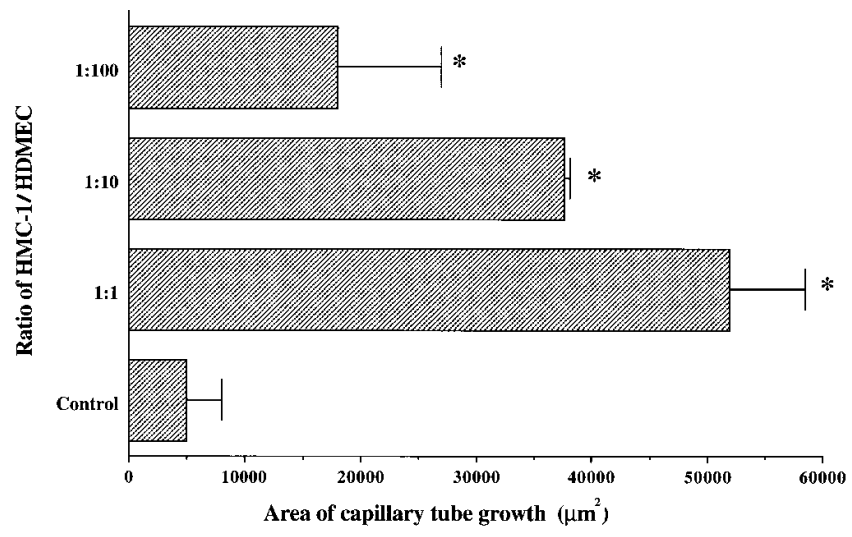

Figure 3. Dose-response relationship between mast cells and the area of HDMEC capillary tube growth. HDMEC $\left(4-5 \times 10^{4}\right)$ were incubated on GFR-Matrigel in 24-well plates. HMC-1 cells were directly added to the wells at ratios of 1:1, 1:10, and 1:100 (HMC-1/ HDMEC) with calcium ionophore A23187. Wells were fixed and stained after $16 \mathrm{~h}$, and then the area of capillary growth was quantitated with MetaMorph Imaging System, an image analysis program. Data are expressed as mean $\pm \mathrm{SD}(n=3)$ from images of random fields at $10 \times$ magnification. Each asterisk indicates that the value is significantly greater than its corresponding control value $(P<0.00003$ for $1: 1 ; P<0.0007$ for $1: 10$; and $P<0.002$ for $1: 100)$.

fecting the Matrigel rather than the endothelial cells directly, the following experiment was performed. Matrigel was preincubated with tryptase in the absence of cells for several hours, and then BABIM was added to inhibit tryptase. The HDMEC were then introduced and incubated as described previously. Endothelial cells added to this tryptase-treated Matrigel failed to form any more tubes than under control conditions, implying that the effect of tryptase is likely to be a direct effect on endothelial cells.

Inhibition of HDMEC tube formation. HMC-1 releasate, pretreated for $30 \mathrm{~min}$ with the tryptase inhibitor BABIM, was added to HDMEC on GFR-Matrigel at the specified concentrations. The pretreatment with a tryptase inhibitor resulted in blunting $88 \%$ of capillary growth compared to the HMC-1 releasate-treated cultures (Fig. 2). The effect of another tryptase inhibitor, rLDTI, was comparable to BABIM (data not shown). Morphologically, HDMEC treated with HMC-1 releasate in the presence of the tryptase inhibitor BABIM formed a minimal number of tubes compared to intact HMC-1 releasate (Fig. 5, $a-c$ ). Moreover, BABIM added directly to HDMEC had no effect on capillary development (Fig. $5 d$ ), and none of the inhibitors were toxic to the cells, as determined by trypan blue exclusion.

To test the specificity of BABIM and rLDTI in the angiogenic response to tryptase, bFGF was pretreated with the tryptase inhibitor and then added to HDMEC. bFGF stimulated $18,957 \mu \mathrm{m}^{2}$ of tube growth, and the addition of tryptase inhibitors (BABIM and rLDTI) had no effect of bFGF-mediated capillary growth (data not shown). Likewise, the phorbol ester PMA induced tube formation that was not suppressed by pretreatment with BABIM or rLDTI.

Lastly, to directly address whether tryptase must be catalytically intact to mediate tube formation, the following studies were performed. Purified tryptase was pretreated with 

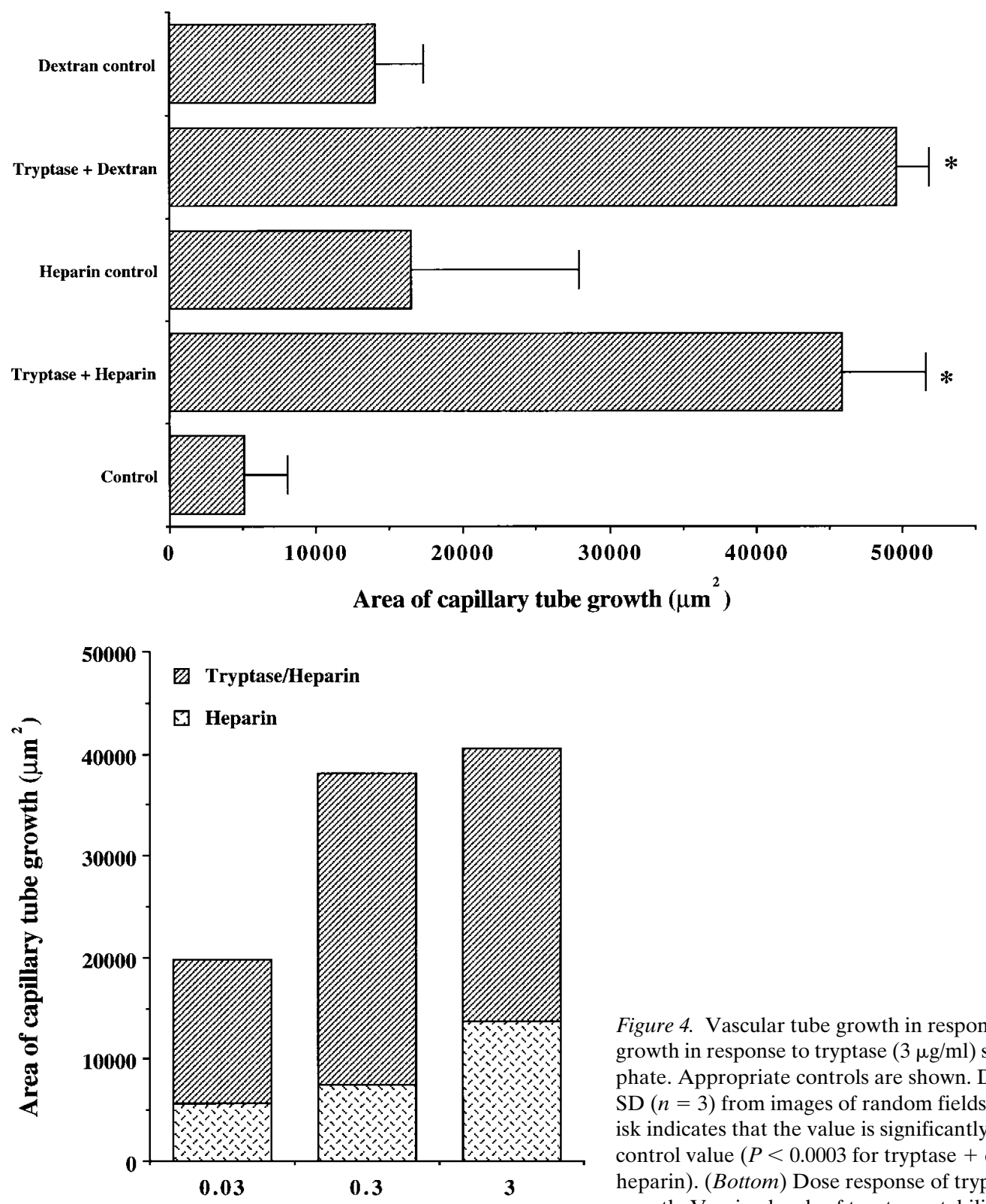

Concentration of tryptase $(\mu \mathrm{g} / \mathrm{ml})$

Figure 4. Vascular tube growth in response to tryptase. (Top) Vascular growth in response to tryptase $(3 \mu \mathrm{g} / \mathrm{ml})$ stabilized by heparin or dextran sulphate. Appropriate controls are shown. Data are expressed as the mean \pm $\mathrm{SD}(n=3)$ from images of random fields at $10 \times$ magnification. Each asterisk indicates that the value is significantly greater than its corresponding control value $(P<0.0003$ for tryptase + dextran; $P<0.002$ for tryptase + heparin). (Bottom) Dose response of tryptase effect on vascular tube growth. Varying levels of tryptase, stabilized by heparin at 1.2 molar excess, reveal a stimulatory effect at concentrations as low as $30 \mathrm{ng} / \mathrm{ml}$.

BABIM or rLDTI, and the effect on capillary tube growth was analyzed (Fig. 6). BABIM was able to inhibit $73 \%$ of tube formation compared to intact tryptase, while rLDTI produced comparable (71\%) inhibition (Fig. 6). Tryptase, which was allowed to separate into the proteolytically inactive monomeric form in the absence of glycosaminoglycans, was also incapable of inducing tube formation over basal levels. The subsequent addition of heparin did not restore proteolytic activity nor the ability to induce tube formation (data not shown).

Endothelial cell tube formation on collagen gels. To examine tube formation on an extracellular matrix that is inherently less conducive for rapid neovascularization, HDMEC were cultured on collagen gels in the presence or absence of stimulants. Confluent cultures of endothelial cells on the collagen gels appeared as a monolayer of interlocking cells (Fig. $7 a$ ). $4 \mathrm{~h}$ after PMA was added, the cells became elongated and spin- dle shaped, but bFGF and HMC-1 releasate did not induce any immediately noticable changes in cell shape (data not shown). After $48 \mathrm{~h}$, numerous tubes were visible in the wells treated with PMA. Cells treated with bFGF did not form a significant number of tubes until $72 \mathrm{~h}$ after treatment. HMC-1 releasate induced tube formation between 48 and $72 \mathrm{~h}$ after treatment. The plane of focus of the tubes in all the treated wells was clearly below the surface, where a monolayer still existed (Fig. $7, b$ and $c$ ). A scattered network of tubes was visible $24 \mathrm{~h}$ after tube formation began. After $72 \mathrm{~h}$, the cultures were aspirated, and the cells were restimulated with fresh media supplemented with the appropriate stimulant. By day 7 , a dense network of capillary-like structures formed in all the treated wells. The controls remained in the characteristic monolayer without any discernible tube growth. By day 10 , a majority of the tubes extended deep into the collagen gel, and the experiment was 

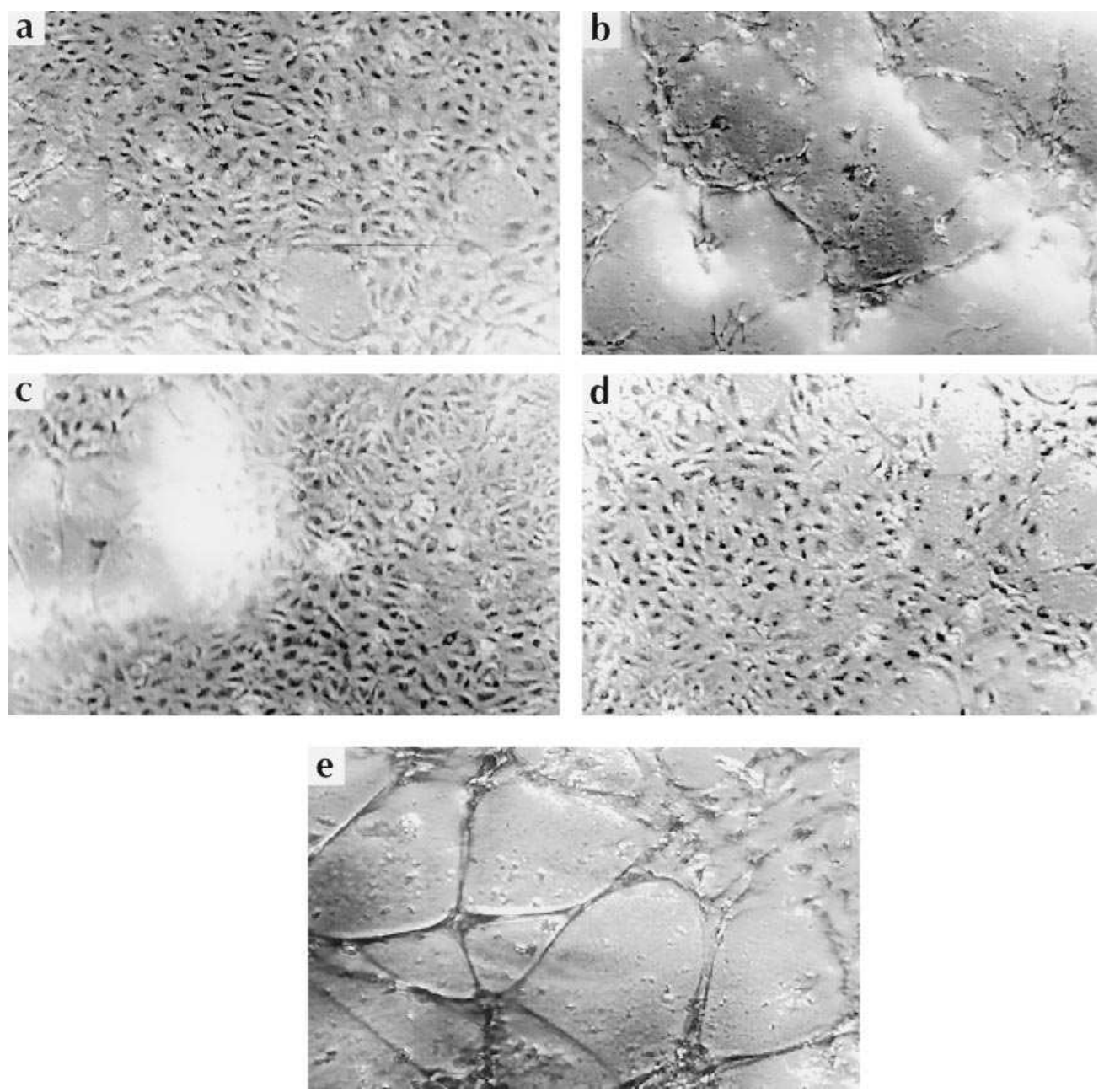

Figure 5. Inhibition of HDMEC vascular tube growth. HDMEC $\left(4-5 \times 10^{4}\right)$ were incubated on GFR-Matrigel in 24-well plates. HMC-1 releasate (1:10 dilution) with or without BABIM $(50 \mathrm{nM})$ or, alternatively, tryptase ( $3 \mu \mathrm{g}$ / $\mathrm{ml}$ ) alone was added to the wells after a 30-min preincubation. Plates were incubated for $16 \mathrm{~h}$ and then fixed and stained. Photographs were taken at various time points with a Nikon N2000 camera on a phase microscope at $4 \times$ magnification, as described. (a) Control showing HDMEC without any additional stimuli. (b) HMC-1 releasate added to HDMEC. (c) HMC-1 releasate pretreated with BABIM added to HDMEC. $(d)$ BABIM control added directly to HDMEC. (e) Tryptase directly added to HDMEC. terminated and analyzed. Concentrations of PMA and bFGF of $30 \mathrm{ng} / \mathrm{ml}$ or greater were adequate to stimulate this process. HMC-1 releasate resulted in tube formation on these collagen gels comparable to bFGF.

Confocal microscopic and ultrastructural analysis of in vitro capillary tubes. Reflective confocal microscopy, with computer-asssisted reconstruction of the images to provide a crosssectional analysis, revealed tube-like structures with circular appearances (Fig. 8, inset). The ultrastructure of HDMEC, plated on Matrigel and incubated with HMC-1 releasate, was also analyzed by scanning electron microscopy. Tubular structures resembling in vivo capillaries extended out from their cell bodies of origin (Fig. $8 a$ ). Individual tubes formed connections with other developing capillaries (Fig. $8 b$ ) to create an interconnecting network of maturing vessels. In earlier steps of the developmental process, several tubes were seen as open channels that appeared to seal apically (Fig. $8 c$ ). In some sections, we observed that closure was initiated by the walls on each side of the tube rising upward to meet in the middle (Fig. $8 \mathrm{c}$, arrows). In the final process of vessel formation, the in vitro-generated tubes resembled in vivo capillaries, with only an occasional small aperture remaining on the superior surface of the vessel (Fig. $8 d$, arrow).

Endothelial cell proliferation. Tryptase, incubated with HDMEC for $72 \mathrm{~h}$, markedly enhanced cell proliferation (Fig.
9). Heparin alone was capable of inducing cell proliferation, but to a much lower degree, as compared to tryptase/heparin. The maximal proliferative response was comparable to $5 \%$ serum. A dose response to tryptase was observed ( $2 \mathrm{pM}-2 \mathrm{nM})$. Thus, enzymatically stabilized tryptase directly induces microvascular endothelial cells to proliferate in the absence of a matrigel or collagen substratum.

\section{Discussion}

A better understanding of how mast cells participate in angiogenesis is critical to further our knowledge about vascular development and remodeling. Mast cells reside mainly in connective tissue and are often found near small vessels. They are involved in regulating the microcirculation and controlling traffic of cells in tissues (25). Eady et al., found a correlation between the number of mast cells and the density of blood vessels in the dermis, suggesting a role for mast cells in angiogenesis (26). Additional support was derived from an analysis of angiogenesis on the chick chorioallantoic membrane. An increased number of mast cells was noted immediately before new blood vessels appeared, implying an active role in angiogenesis (27). More recently, investigators demonstrated that stimulation of mast cells within the chick chorioallantoic membrane leads to proliferation of microvessels (28). In addition, 


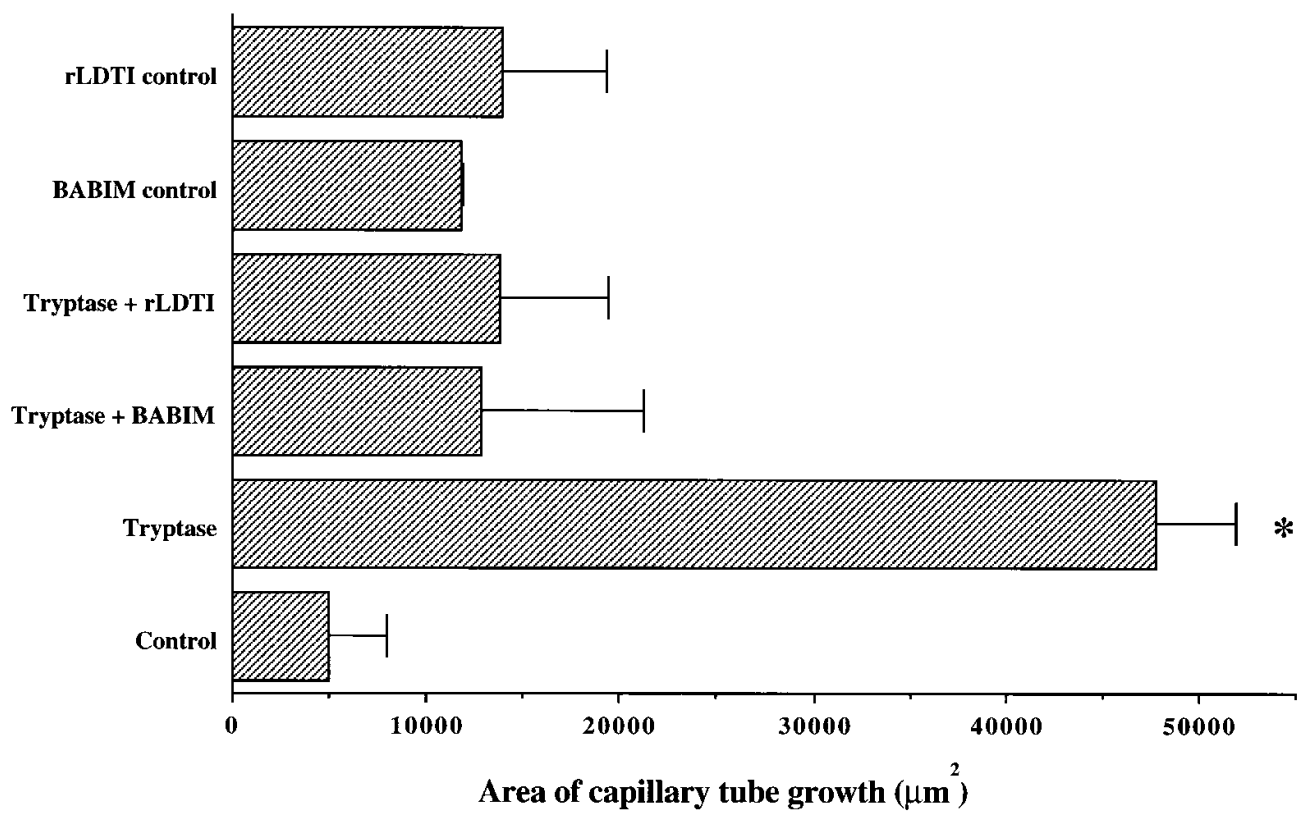

Figure 6. The effect of tryptase proteolytic inhibitors on vascular tube growth mediated by tryptase. Tryptase $(3 \mu \mathrm{g} / \mathrm{ml})$, preincubated for $30 \mathrm{~min}$ with either BABIM (50 nM), rLDTI $(25 \mu \mathrm{M})$, or culture media alone, was added to 24-well plates coated with GFR-Matrigel. Data are expressed as the mean $\pm \mathrm{SD}$ $(n=3)$ from images of random fields at $10 \times$ magnification. The asterisk indicates that the value is significantly greater than its corresponding control value $(P<0.003)$.
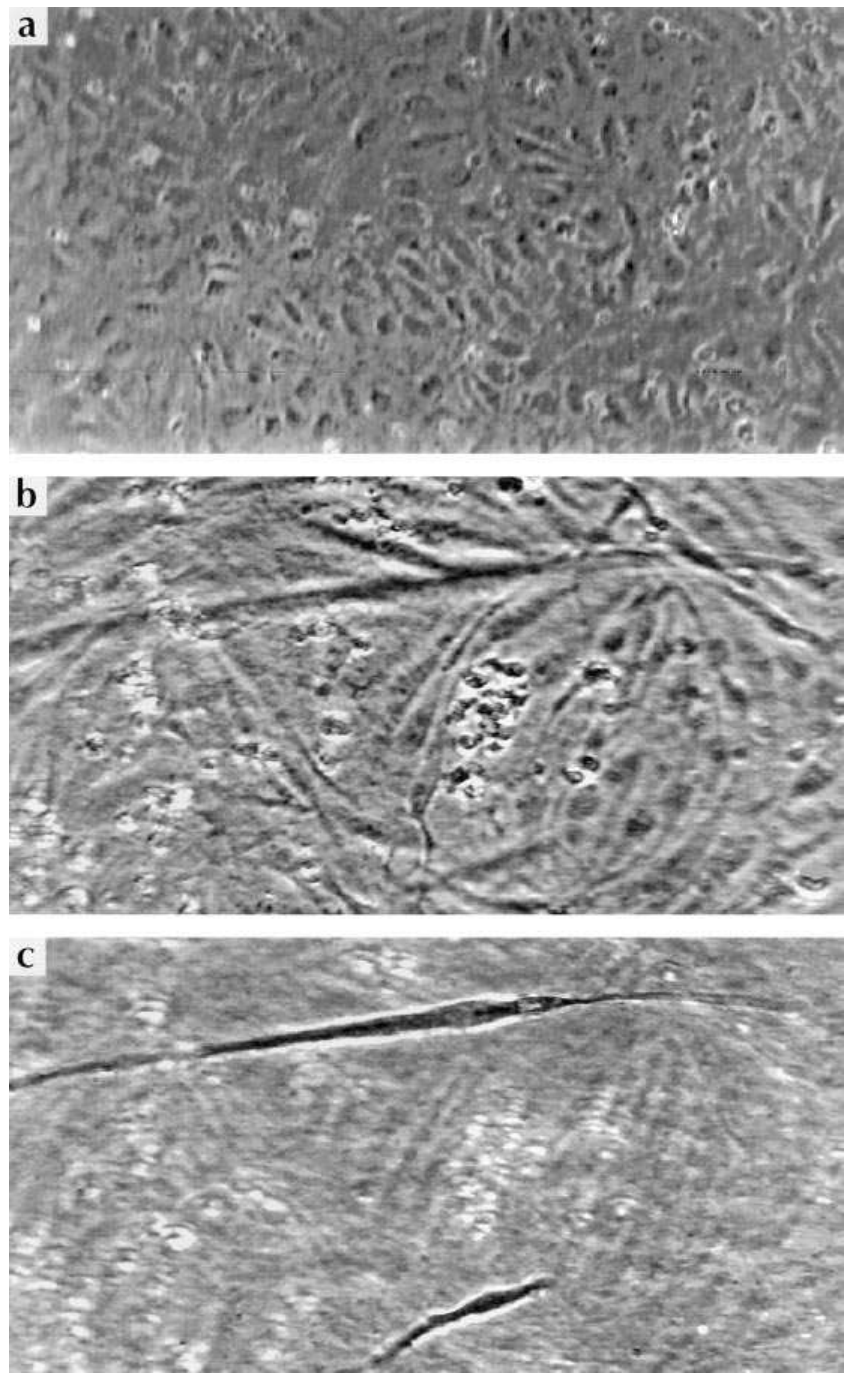

preliminary studies of tumor implants in mast cell-deficient mice, as compared to mast cell-replete litter mates, reveal a substantial influence of mast cells in allowing neoplastic tissue to invade and vascularize the host tissue (29).

Despite these observations, the precise mechanism by which mast cells act at these neovascular sites is largely unknown. Mast cells conceivably may contribute to any of a number of events related to angiogenesis, including dissolution of extracellular matrix, migration of endothelial cells, or stimulation of cell proliferation and differentiation $(30,31)$. Recently, mast cells have been shown to be a rich source of several potent angiogenic factors, including bFGF, TGF- $\beta$, and VEGF/ VPF (32-34). The present study provides confirmation for a direct association between mast cells and vascular tube formation. Furthermore, we identified a critical component secreted by mast cells (i.e., tryptase) that is responsible for mediating angiogenesis under these experimental conditions.

A variety of in vitro models have been used to study angiogenesis. We selected two slightly different models and compared the effect of mast cells on the extent of microvascular capillary tube formation. By culturing HDMEC on an isolated basement membrane substratum (GFR-Matrigel), capillary formation occurred de novo, albeit limited. In contrast, HDMEC cultured on purified collagen type I matrix essentially abolished tube formation in the absence of stimuli. The first evidence of tube growth on collagen was not discernable

Figure 7. Effect of PMA on HDMEC tube formation on collagen gel. HDMEC $\left(10^{5}\right)$ were seeded on collagen gel in 24 -well plates. Cultures were stimulated with PMA ( $30 \mathrm{ng} / \mathrm{ml})$, fixed after $72 \mathrm{~h}$ incubation, and photographed with a Nikon N2000 camera on a phase microscope at $4 \times$ magnification, as described in Methods. (a) Control. (b) PMA; view of the layer of cells on top of the gel. (c) PMA; identical field of view as $b$, but, the focus is within the gel. 

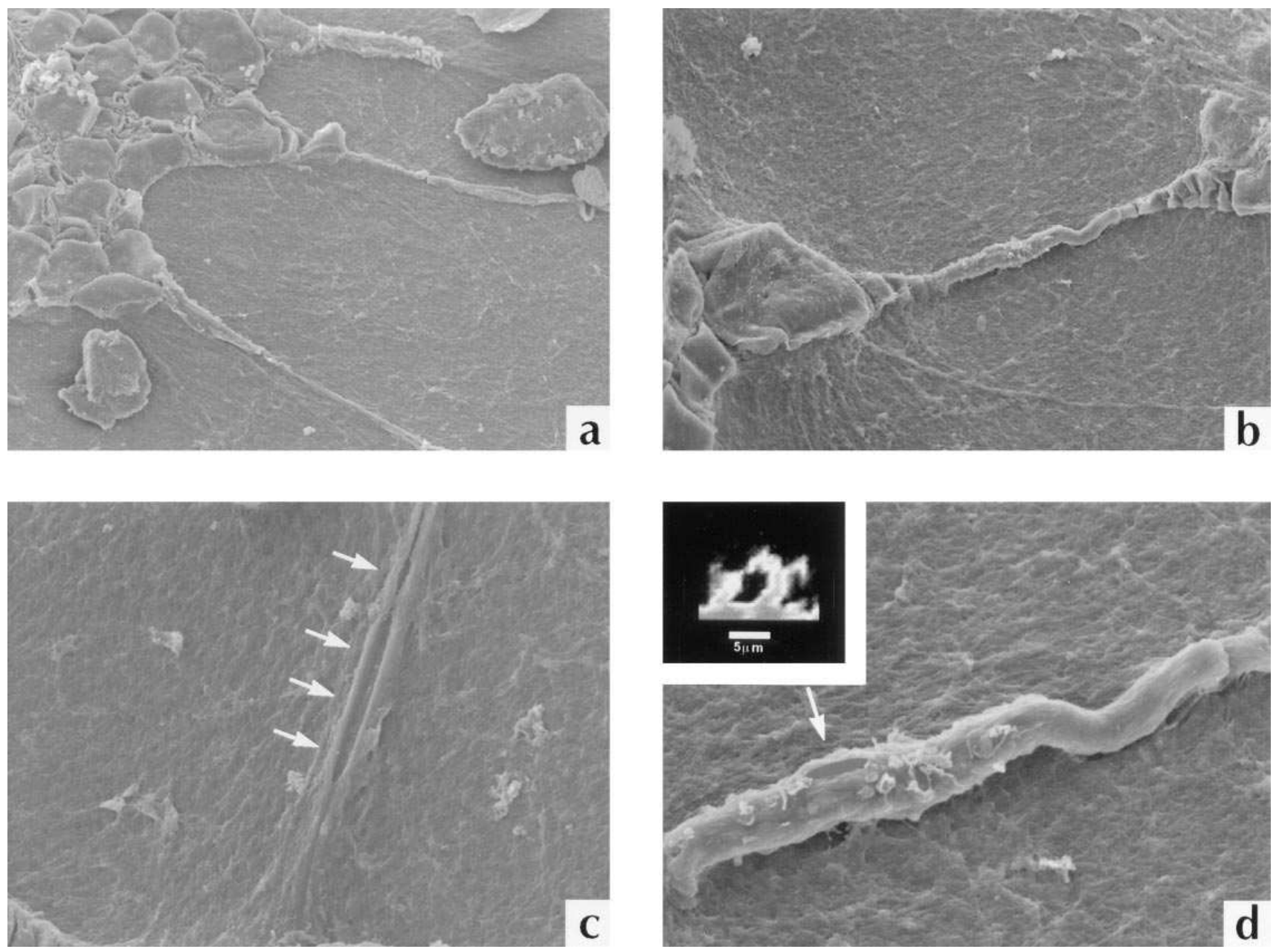

Figure 8. Representative scanning electon micrographs revealing HDMEC capillary tube morphology. HDMEC $\left(4-5 \times 10^{4}\right)$ were seeded on $500 \mu \mathrm{l}$ GFR-Matrigel and were incubated with HMC-1 releasate (1:10 dilution) for $16 \mathrm{~h}$. Wells were fixed with $2.5 \%$ glutaraldehyde and $2 \%$ paraformaldehyde and then washed in $2 \times$ PBS. (a) The classic cobblestone morophology of HDMEC is seen on the left. The tubes arise as processes from cell bodies and extend outward toward other developing vessels $(\times 350)$. $(b)$ A single tube bridges two adjacent cell bodies $(\times 500)$. (c) A tube in the early stages of development reveals incomplete closure (arrows) of its capillary walls $(\times 1,000)$. $(d)$ The arrow points to an area of a more mature vessel that has not yet sealed $(\times 1,500)$. (Inset) A cross-sectional photomicrograph using reflective confocal microscopy reveals a cylindrical capillary-like structure of HDMEC morphology on Matrigel after stimulation with tryptase.

until a minumum of $24 \mathrm{~h}$, whereas tubes appeared on Matrigel within 1-2 h after plating, as previously reported (16). Based on our initial results, we performed a majority of the experiments on GFR-Matrigel. Nonetheless, we observed that mast cell products induced angiogenesis within the less permissive microenvironment of purified type I collagen.

Ultrastructural analysis using the scanning electron microscope and reflective confocal microscopy confirmed that the endothelial cell structures that formed were indeed threedimensional tubes. The tubes appeared to seal at the apical surface over time. Previously, Folkman et al. described capillary tube formation using endothelial cells cultured on plastic in tumor-conditioned medium (35). In contrast, Zimrin et al. dispute these findings and contend that human umbilical veinderived endothelial cells cultured on Matrigel develop morphologic changes that are neither dependent on new transcription or translation, nor represent cylindrical tube formation (23). Our experimental model system, which differs by using human microvascular endothelial cells on a GFR-Matrigel substratum, was clearly dependent on transcriptional and translational events, since actinomycin D or cycloheximide totally abrogated tube formation. In addition, scanning electron microscopy indicated tube formation, and reflective confocal microscopy confirmed the formation of cylindrical structures (Fig. 8). Our results are similar to earlier studies by Kubota et al. (36), demonstrating that human microvascular endothelial cells formed capillary-like structures on Matrigel, as revealed by transmission electron microscopy. Differences in experimental conditions, including the use of microvascular endothelial cells and GFR-Matrigel supports, may explain the discrepant results when using these in vitro models of angiogenesis.

In a series of experiments, we examined the effect of HMC-1 products on capillary tube growth in GFR-Matrigel and type I collagen. The HMC-1 mast cell line represents a reasonable alternative to native human mast cells, which are difficult to obtain in large enough quantity or to propogate in culture to use 


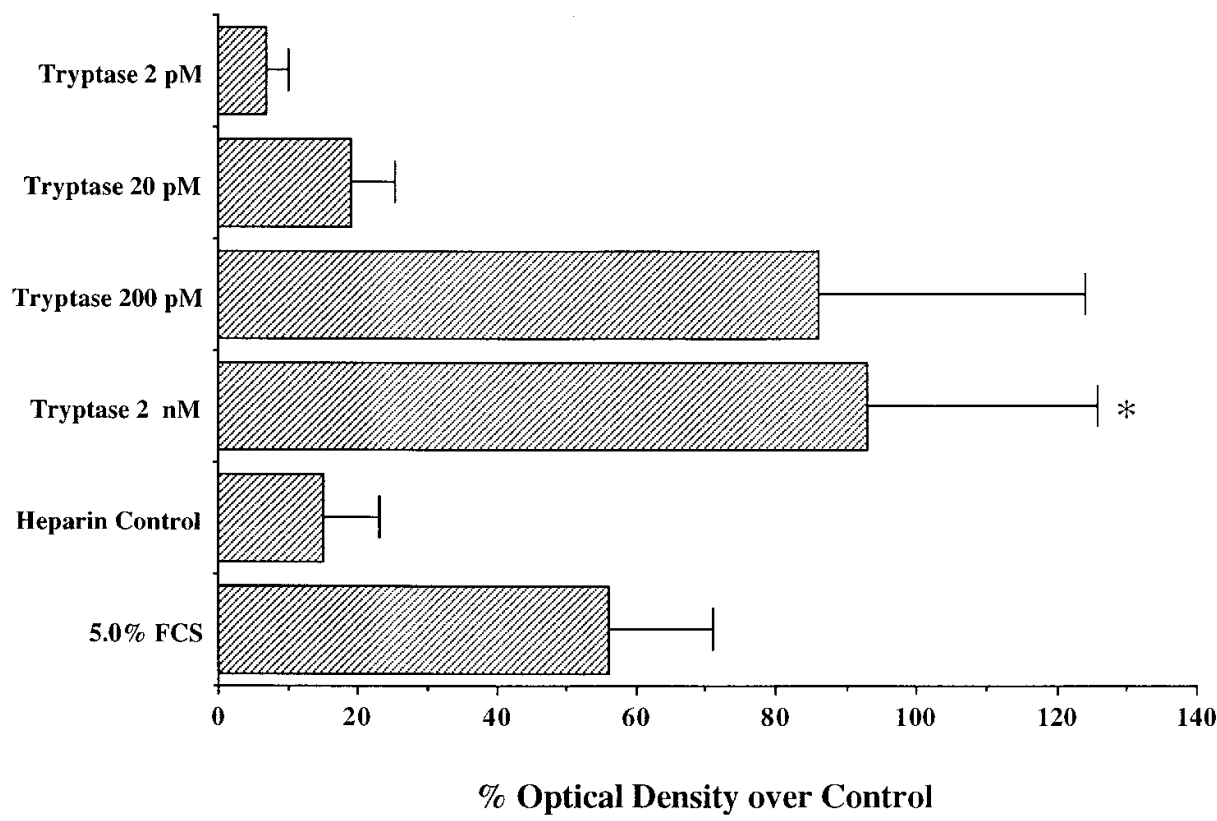

Figure 9. Microvascular endothelial cell proliferation in response to varying concentrations of tryptase. HDMEC $\left(5 \times 10^{4}\right.$ cells $\left./ \mathrm{ml}\right)$ were partially serumstarved in $2 \%$ serum, allowed to adhere at $37^{\circ} \mathrm{C}$ for $4-6 \mathrm{~h}$, and then exposed to varying concentrations of tryptase (as indicated) stabilized with heparin, heparin alone, or $5 \%$ serum for $72 \mathrm{~h}$. The resulting number of viable HDMECs was determined using a nonradioactive colorimetric cell proliferation assay. Data are expressed as the mean percent over control ( $2 \%$ serum $) \pm$ SEM of three experiments, with each concentration performed in triplicate wells.

The asterisk indicates that the value is significantly greater than its corresponding control value $(P<0.05)$. for experimental purposes. HMC-1 cells release numerous cytokines, proteoglycans, and tryptase $(19,37,38)$ similar to mature human mast cells. However, the lack of $\mathrm{Fc}_{\epsilon} \mathrm{RI}$ membrane receptors and the general cytoplasmic morphology of the HMC-1 cells reflect their immature stage of differentiation (18). Thus, experimental findings using HMC-1 cells will require further confirmation with mature isolated human mast cells.

Within these confines, our studies revealed that HMC-1conditioned media greatly enhanced the anastomosing network of capillary sprouting. Cocultures of HMC-1 cells with HDMEC also resulted in significant vascular tube development, especially after mast cell secretion. As the HMC-1/HDMEC cell number ratio approached unity, the network of capillaries increased in a dose-response manner. The number of mast cells per endothelial cell used in these experiments was typical of physiological conditions, since even at ratios of 1:100 (HMC-1 to HDMEC), a significant increase in capillary tube growth was observed.

Additional experiments were performed to assess the role of tryptase in mediating mast cell-induced angiogenesis. By pretreating the HMC-1-conditioned media with specific tryptase inhibitors, we observed a marked decrease in the area of capillary growth. In contrast, the addition of these inhibitors to bFGF and PMA did not affect the angiogenic response, confirming the specificity of these compounds in this experimental setting.

To further investigate the hypothesis that tryptase induces angiogenesis, we directly added highly purified human tryptase to HDMEC on Matrigel. We observed that tryptase markedly stimulated more than a 10 -fold increase in the area of capillary tubes. This increase was also significant when compared to stimulation with the stabilizing glycosaminoglycans alone (heparin or dextran). A typical dose response for purified tryptase was established. The concentration of tryptase within this dose range could easily be achieved in tissue, assuming an average mast cell tissue density of $\sim 7,000 / \mathrm{mm}^{3}$ and $\sim 35 \mathrm{pg}$ tryptase/mast cell (39).
Although heparin has been shown to be angiogenic itself (35), we found that tube growth is minimal compared to levels achieved with tryptase. A dose response study indicated that heparin alone accounts only for $\sim 25 \%$ of the large increase in tube growth mediated by tryptase. This angiogenic effect requires tryptase to be catalytically active, since synthetic tryptase inhibitors were able to abolish the effect. It is interesting to note that, to date, no native mammalian inhibitors of tryptase have been identified (11). The future identification of a nontoxic or native tryptase inhibitor might greatly enhance the ability to control the balance of angiogenic activity in human diseases (40).

Based on this data, it appears that tryptase, released from mast cells at a site of new blood vessel growth, may play an important role in neovascularization. The precise mechanism by which tryptase stimulates neovascularization is not yet clear. We observed that in our model system, tryptase influences the endothelial cells directly, rather than "conditioning" the surrounding matrix. Since endothelial cells did not form substantial tubes on Matrigel pretreated with tryptase, we believe that tryptase interacts directly on endothelial cells via an unidentified mechanism to induce angiogenesis. The concept that enzymes have direct angiogenic properties has previously been reported (41). Furthermore, tryptase is known to function as a mitogen for fibroblasts, smooth muscle cells, and epithelial cells (42-44). We also demonstrated that tryptase can function as a mitogen for dermal microvascular endothelial cells (Fig. 9). Thus, it is clear that tryptase may directly mediate microvascular endothelial cell activation, and the mechanism of promoting tube formation is unlikely a result of an indirect effect on the surrounding matrix. Tryptase also activates latent metalloproteinases and plasminogen activator $(45,46)$, which function to degrade the extracellular matrix. Such degradation is critical in the early stages of angiogenesis.

Thus, tryptase may induce the formation of capillary structures by either directly acting on endothelial cells or by facilitating the initial steps of the process. Future studies are underway to elucidate the specific mechanism by which tryptase 
stimulates blood vessel formation. Such knowledge may lead to novel means of controlling pathological conditions that are dependent on angiogenesis.

\section{Acknowledgments}

This research was supported by funds available from the Arthritis Foundation and the American College of Rheumatology Medical student fellowship (R.J. Blair), American Heart Association (B.L. Gruber), and National Institutes of Health grants AI20487 and AI27517 (L.B. Schwartz).

\section{References}

1. Brooks, P., R.A.F. Clark, and D.A. Cheresh. 1994. Requirement of vascular integrin $\alpha \mathrm{v} \beta 3$ for angiogenesis. Science (Wash. DC). 264:569-571.

2. Findaly, J.K. 1986. Angiogenesis in reproductive tissues. J. Endocrinol. 111:357-366

3. Folkman, J., D.K. Long, and F.F. Becker. 1963. Growth and metastasis of tumor in organ culture. Cancer. 16:453-467.

4. Engerman, R.L. 1989. Pathogenesis of diabetic retinopathy. Diabetes. 38 : 1203-1206.

5. Meininger, C.J., and B.R. Zetter. 1992. Mast cells and angiogenesis. Cancer Biol. 3:73-79.

6. Furcht, L.T. 1986. Critical factors controlling angiogenesis: cell products, cell matrix, and growth factors. Lab. Invest. 55:505-509.

7. Roche, W.R. 1985. Mast cells and tumour angiogenesis: the tumourmediated release of an endothelial growth factor from mast cells. Int. J. Cancer. 36:721-728.

8. Gruber, B.L., M.J. Marchese, and R.R. Kew. 1995. Angiogenic factors stimulate mast cell migration. Blood. 86:2488-2493.

9. Montesano, R., M.S. Pepper, U. Mohle-Steinlein, W. Risau, E.F. Wanger, and L. Orci. 1990. Increased proteolytic activity is responsible for the aberrant morphogenetic behavior of endothelial cells expressing middle $\mathrm{T}$ oncogene. Cell. 62:435-445.

10. Schwartz, L.B., R.A. Lewis, and K.F. Austen. 1981. Tryptase from human pulmonary mast cells: purification and characterization. J. Biol. Chem. 256: 11939-11943.

11. Schwartz, L.B. 1994. Tryptase: a mast cell serine protease. Methods Enzymol. 244:88-100.

12. Xia, H.-Z., C.L. Kepley, K. Sakai, J. Chelliah, A.-M.A. Irani, and L.B. Schwartz. 1995. Quantitation of tryptase, chymase, FceRI $\alpha$, and FceRIgamma mRNAs in human mast cells and basophils by competitive reverse transcription-polymerase chain reaction. J. Immunol. 154:5472-5480.

13. Sakai, K., S. Ren, and L.B. Schwartz. 1996. A novel heparin-dependent processing pathway for human tryptase: autocatalysis followed by activation with dipeptidyl peptidase I. J. Clin. Invest. 97:988-995.

14. Caughey, G.H., W.W. Raymond, E. Bacci, R.J. Lombardy, and R.R. Tidwell. 1993. Bis(5-amidino-2-benzimidazolyl)methane and related amidines are potent, reversible inhibitors of mast cell tryptases. J. Pharmacol. Exp. Ther. 264:676-682

15. Sommerhoff, C., C. Sollner, R. Mentele, G. Piechottka, E. Auerswald, and H. Fritz. 1994. A kazal-type inhibitor of human mast cell tryptase: isolation from the medical leech Hirudo medicinalis, characterization and sequence analysis. Biol. Chem. Hoppe Seyler. 375:685-694.

16. Kubota, Y., H. Kleinman, G.R. Martin, and T.J. Lawley. 1988. Role of laminin and basement membrane in the differentiation of human endothelial cells into capillary-like structures. J. Cell Biol. 107:1589-1598.

17. Meng, H., M.J. Marchese, J.A. Garlick, A. Jelaska, J.H. Korn, J. Gailit, R.A.F. Clark, and B.L. Gruber. 1995. Mast cells induce T-cell adhesion to human fibroblasts by regulating ICAM-1 and VCAM-1 expression. J. Invest. Derm. 105:789-796.

18. Butterfield, J.H., D. Weiler, G. Dewald, and G.J. Gleich. 1988. Establishment of an immature mast cell line from a patient with mast cell leukemia. Leukemia Res. 12:345-355.

19. Butterfield, J.H., D.A. Weiler, L.W. Hunt, S.R. Wynn, and P.C. Roche, 1990. Purification of tryptase from a human mast cell line. J. Leukocyte Biol. 47: 409-419.

20. Irani, A.M., T.R. Bradford, C.L. Kepley, N.M. Schecter, and L.B. Schwartz. 1989. Detection of MCt and MCtc types of human mast cells by immunohistochemistry using new monoclonal anti-tryptase and anti-chymase an- tibodies. J. Histochem. Cytochem. 37:1509-1515.

21. Montesano, R., and L. Orci. 1985. Tumor-promoting phorbol esters induce angiogenesis in vitro. Cell. 42:469-477.

22. Kleinman, H.K., M.L. McGarvey, and J.R. Hassel. 1986. Basement membrane complexes with biological activity. Biochemistry. 25:312-318.

23. Zimrin, A.B., B. Villeponteau, and T. Maciag. 1995. Models of in vitro angiogenesis: endothelial cell differentiation on fibrin but not matrigel is transcriptionally dependent. Biochem. Biophys. Res. Commun. 213:630-638.

24. Alter, S.C., D.D. Metcalfe, T.R. Bradford, and L.B. Schwartz. 1987. Regulation of human mast cell tryptase. Biochem. J. 248:821-827.

25. Gruber, B.L., and A.P. Kaplan. 1993. Mast cells and rheumatic diseases. In Arthritis and Allied Conditions. D.J. McCarty and W.J. Koopman, editors. Lea and Febiger, Philadelphia. 417-436.

26. Eady, R.A.J., T. Cowen, T.F. Marshall, V. Plummer, and M.W. Greaves, 1979. Mast cell population density, blood vessel density and histamine content in normal skin. Br. J. Dermatol. 100:635-640.

27. Kessler, D.A., R.S. Langer, N.A. Pless, and J. Folkman. 1976. Mast cells and tumor angiogenesis. Int. J. Cancer. 18:703-709.

28. Rizzo, V., and D.O. DeFouw. 1996. Mast cell activation accelerates the normal rate of angiogenesis in the chick chorioallantoic membrane. Microvasc. Res. 52:245-257.

29. Dethlefsen, S.M., N. Matsuura, and B.R. Zetter. 1990. Tumor growth and angiogenesis in wild type and mast cell deficient mice. FASEB J. 4:A623 (Abstr.).

30. Azizkhan, R.G., J.C. Azizkhan, B.R. Zetter, and J. Folkman. 1980. Mast cell heparin stimulates migration of capillary endothelial cells in vitro. J. Exp. Med. 152:931-944.

31. Ryan, T.J. 1970. Factors influencing the growth of vascular endothelium in the skin. Br. J. Dermatol. 82:99-106.

32. Qu, Z., J.M. Liebler, M.R. Powers, T. Galey, P. Ahmadi, X.N. Huang, J.C. Ansel, J.H. Butterfield, S.R. Planck, and J.T. Rosenbaum. 1995. Mast cells are a major source of basic fibroblast growth factor in chronic inflammation and cutaneous hemangioma. Am. J. Pathol. 147:564-573.

33. Pennington, D.W., A.R. Lopez, P.S. Thomas, C. Peck, and W.M. Gold. 1992. Dog mastocytoma cells produce transforming growth factor- $\beta_{1}$. J. Clin. Invest. 90:35-41.

34. Grutzkau, A., S. Kruger-Krasagakes, H. Kogel, C. Schwarz, B.M. Henz, and A. Moller. 1996. Synthesis, storage, and release of the vascular endothelial growth factor by human mast cells. Mol. Biol. Cell. 7:352A (Abstr.).

35. Folkman, J., and C. Haudenschild. 1980. Angiogenesis in vitro. Nature (Lond.). 288:551-556.

36. Kubota, Y., H.K. Kleinman, G.R. Martin, and T.J. Lawley. 1988. Role of laminin and basement membrane in the morphological differentiation of human endothelial cells into capillary-like structures. J. Cell. Biol. 107:1589-1598.

37. Grabbe, J., P. Welker, A. Moller, E. Dippel, L.K. Ashman, and B.M. Czarnetzki. 1994. Comparative cytokine release from human monocytes, monocyte-derived immature mast cells, and a human mast cell line (HMC-1). $J$. Invest. Dermatol. 103:504-508.

38. Nilsson, G., V. Svensson, and K. Nilsson. 1995. Constitutive and inducible cytokine mRNA expression in the human mast cell line HMC-1. Scand. $J$. Immunol. 42:76-81

39. Irani, A.A., B.L. Gruber, L.D. Kaufman, M.B. Kahaleh, and L.B. Schwartz. 1992. Mast cell changes in scleroderma. Presence of MCt cells in the skin and evidence of mast cell activation. Arthritis Rheum. 35:933-939.

40. Folkman, J. 1995. Angiogenesis in cancer, vascular, rheumatoid and other disease. Nature Medicine. 1:27-31.

41. Haraguchi, M., K. Mitadera, K. Uemura, T. Sumizawa, T. Furukawa, K. Yamada, and S. Akiyama. 1994. Angiogenic activity of enzymes. Nature (Lond.). 368:198-201.

42. Brown, J.K., C.A. Jones, C.L. Tyler, S.J. Ruoss, T. Hartmann, and G.H Caughey. 1995. Tryptase-induced mitogenesis in airway smooth muscle cells. Chest. 107:95S-96S

43. Hartmann, T., S.J. Ruoss, W.W. Raymond, K. Seuwen, and G.H. Caughey. 1992. Human tryptase as a potent, cell-specific mitogen: role of signaling pathways in synergistic responses. Am. J. Physiol. 262:L528-L534.

44. Cairns, J.A., and A.F. Walls. 1996. Mast cell tryptase is a mitogen for epithelial cells: stimulation of IL-8 production and intercellular adhesion molecule-1 expression. J. Immunol. 156:275-283.

45. Gruber, B.L., M.J. Marchese, K. Suzuki, L.B. Schwartz, Y. Okada, H. Nagase, and N.S. Ramamurthy. 1989. Synovial procollagenase activation by human mast cell tryptase dependence upon matrix metalloproteinase 3 activation. J. Clin. Invest. 84:1657-1662.

46. Stack, M.S., and D.A. Johnson. 1994. Human mast cell tryptase activates single-chain urinary-type plasminogen activaor (pro-urokinase). J. Biol. Chem. 269:9416-9419. 